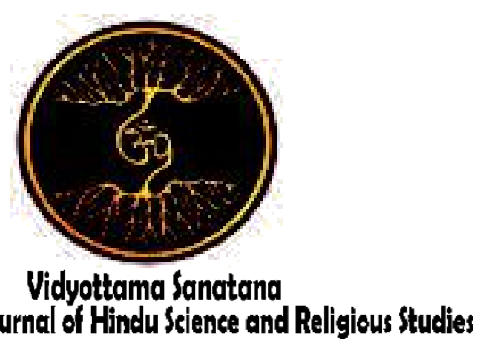

Vol. 5 No. 2 October 2021

\title{
AESTHETICS AND ETHICS OF KARAWITAN ART IN LONTAR AJI GHURNNITA
}

\section{By:}

\author{
I Putu Ariyasa Darmawan', Ayu Veronika Somawati², Ida Bagus Putu Eka Suadnyana ${ }^{3}$ \\ ${ }^{1,2,3}$ STAHN Mpu Kuturan Singaraja. \\ E-mail: ${ }^{1}$ ariyasabent23@gmail.com, ${ }^{2}$ ayuvero90@gmail.com, ${ }^{3}$ idabaguseka09@gmail.com
}

\begin{tabular}{|l|l|l|}
\hline Received: June 15, 2021 & Accepted: June 18, 2021 & Published: October 31, 2021 \\
\hline
\end{tabular}

\begin{abstract}
Art is a form of expression of the soul that cannot be separated from human beings. Art makes human's life more beautiful and colorful. Various kinds of art forms were created by humans as a form of existence and self-expression, be it in the form of dance, painting, and various other types of art. Bali as one of the world's international tourist destinations cannot be separated from the various kinds of arts in it. One of them is karawitan or art of sound. Karawitan art itself is divided into two types, namely instrumental musical art in the form of gamelan, and vocal karawitan. The art of karawitan, especially gamelan in Bali, is not only a complement to religious ceremonies or the pouring of creative ideas, but also has a very significant influence on the Balinese people and the listeners of the gamelan. The shape of the gamelan is also able to influence the soul and human behavior that dissolves in the atmosphere brought by the gamelan players. The implementation of gamelan art, either directly or indirectly, has ethical and aesthetic values. Through gamelan art, humans will learn ethical and aesthetic values. If viewed from the aesthetic value, gamelan art contains the values of truth (Satyam), purity (Shivam), and beauty (Sundaram) which are concepts of Hindu aesthetics itself. In terms of ethical values, gamelan art teaches one to learn to respect one another and learn the meaning of equality where everyone has the same position according to their respective duties and functions. Through gamelan, humans learn to harmonize what is said and what is done.
\end{abstract}

Keywords: aesthetics, ethics, karawitan arts 


\section{INTRODUCTION}

Gamelan in Bali is not only a form of respect for God Almighty through the concept of being sincere in carrying out religious ceremonies, but also being able to serve as a means of expressing ideas and creativity in the arts in Bali. Asnawa (2007:27) in his book explains that the word gamelan or gambelan is rooted in the word gamel or gambel which means to be held or acted upon. So the association of the word gamel or gambel in this context is an ideal transposition that relates specifically to musical practice, namely: the attitude of playing (maner of playing) and the way or technique (technique of playing) playing gamelan art. Based on the information above, Balinese gamelan is a means of pouring art and a way of conveying devotion to God Almighty through an activity or activities that are carried out together in a gamelan. Gamelan or Karawitan Art in Bali is not only a media for supporting religious ceremonies, but also as a medium for character education, ethics and aesthetics.

\section{METHOD}

The method used in this article is literature study. This article was compiled by examining books, similar scientific articles, and references related to aesthetics, ethics, and gamelan art. A review of similar research is also carried out to obtain valid conclusions.

\section{Results and Discussion \\ 3.1 Karawitan Arts}

Bandem (2013: 1) in his book explains that the term Karawitan comes from the word rawit which means smooth or beautiful, gets the prefix ka- and the suffix -an, becomes karawitan which means the art of instrumental and vocal sound using pelog barrels (scales) and selendro. Balinese instrumental karawitan is called gamelan, and vocal karawitan is called tembang or sekar. Tim (2008:625) explained that karawitan is the art of gamelan and sound art with the scales of selendro and pelog. Bandem (2013:16) estimates that Balinese Gamelan has existed from prehistoric times to its development to the present day. While the oldest gamelan has been found in prehistoric times, its shape is almost the same as the music found in the interior of Kalimantan, Sulawesi, Sumatra, Java, and several other areas in Indonesia.

As a means of worshiping God, of course, instrumental or gamelan musical instruments are sacred. Darmawan (2019: 51-54) describes that Lontar Aji Ghürṇnita describes the philosophy of creating the main gamelan currently available, namely Smara Pagulingan, Smar Patangyan, Smar Palinggyan, Smar Pandiryan, Selonding, Babonangan, and Gong inspired by gamelan strains from Smaralaya, the palace of the gods. Smara, named Mlad Prana or Gambuh, was finally imitated by Dewa Indra as Smara Pagulingan, Dewa Yama created Smar Patangyan, Dewa Baruna created Smar Palinggyan, Dewa Kuwera created Smar Pandiryan, a hermit in the middle of the forest in worship of the greatness of God Almighty created Barungan Selonding, Bhuta When imitating Mlad Prana with a simple form and having a very vibrant voice is named Babonangan, and Dewata Nawa Sanga and the priests imitating Mlad Prana with a very solemn and authoritative tone of voice are named Gong.

Each blade or part of the gamelan has a divine philosophical value, namely having their respective gods and controlling the cardinal directions, namely the sound of dang symbolizing the god Iswara, deng symbolizing the god Brahma, dong symbolizing the god Mahadewa, dung symbolizing the god Vishnu, ding symbolizing the god Shiva, ndang symbolizing the goddess Mahadewi, ndeng symbolizing the goddess Saraswati, ndong symbolizing the goddess Gayatri, ndung symbolizing the goddess Sri Dewi, and nding symbolizing the goddess Uma Dewi. Because of its holiness, gamelan 
instruments are purified during Tumpek Krulut or on Saturday Kliwon wuku Krulut.

All gamelan sounds are heard by the ear, from the ear it is transmitted to the other senses. This is confirmed by Suweca (2007: 82), that musical taste can be defined as an expression or human expression that can be enjoyed through auditive media. The sense of the audience is basically the ear, but when the enjoyment continues deeper, many senses ultimately play a role in being able to enjoy the auditive taste. As a means of entertainment, music is a recreational medium that is enjoyed in a relaxed and simple manner. Listening to music will be able to direct the human mind for a while towards things that entertain themselves so that problems and daily routines become cured.

\subsection{Aesthetics}

Tim (2002: 309), aesthetics is a branch of philosophy that examines and discusses art and beauty as well as human responses to them; sensitivity to art and beauty. Gie (2004: 119), in the scope of the field of philosophy is now known as one of its branches called "aestheties". The English term is the name of the knowledge of the philosophy of beauty (philosophy of beauty). The word "aestheties" comes from the Greek word aisthesis which means sense perception. This Greek word has a form of aesthetic change which means things that can be perceived with the five senses.

Based on these understandings, art and beauty are part of human life that cannot be separated from human existence itself. The natural needs of humans in the form of things that are pleasant, happy, and immerses themselves make humans incessantly do a creation that produces products in the form of works of art that can be perceived with the five senses to meet the needs of life. This art is not only performed at the level of human profane life, but also at the level of one's spiritual life.
Art in the Hindu perspective has a very basic position. This can be seen from the following quote:

Hindu religious life cannot be separated from art. Yajna ceremonies in holy places (read pura or mandir) cannot be separated from art, such as sound art, dance, karawitan, painting and literature. Places of worship, such as temples, temples, mandir, and so on are built, arranged very beautifully as an expression of the aesthetics, ethics, and religiosity of their adherents. With the involvement of art, the yajna ceremony looks lively and solemn. Every art that is staged is based on a high Hindu religious philosophy (Suamba, 2003: 3).

The existence of gamelan art also cannot be separated from aesthetic values, especially Hindu aesthetics. The basic assumption is that artists and gamelan art connoisseurs certainly have a sense of art which is one of human needs since birth. The artists involved also of course carry out their taste, creativity, and intention when playing this gamelan art. In addition, this gamelan art is an attempt to unite himself with the Creator through the works of art that are created. Creativity is a medium of offering/worshipping God and not for personal (subjective) interests like artists in this modern era, which are full of targets for personal interests only (Yudabakti and Watra, 2007: 28).

In addition, as for the complete characteristics of beauty, both in nature and in works of art, according to Aristotle (in Sumardjo, 2000:175) are: 1) unity or wholeness that can describe the perfection of form, nothing is excessive or reduced, something that is fitting and distinctive, 2) harmony or balance between elements that are proportional, according to their distinctive size, and 3) clarity, that everything gives an impression of clarity, light, clear, pure without any doubt. Based on Aristotle's opinion above about unity or 
wholeness which can describe the perfection of form, harmony or balance between proportional elements, according to their distinctive size, and clarity, then Balinese musical art as a whole, especially gamelan art, meets all the criteria for complete characteristics of beauty according to Aristotle. The integrity of gamelan instruments is very important in the performance, if there is one instrument that is lacking, it is very clearly seen and sounds that are chaotic or inappropriate. It is more inappropriate when the use of gamelan instruments does not match the ceremonial situation with the character of the gamelan sound that is sung, this will destroy the aesthetics of Balinese musical art.

As a work of art created by an artist, gamelan art is not only made to be enjoyed solely by the human senses or gamelan art connoisseurs, especially the sense of hearing. Gamelan art is created not only as a medium for worshiping the artist to Ida Sang Hyang Widhi Wasa, but also as a medium to bring people closer to Him. The result of the work of art in question is not merely to see how the physical form is produced by the artists who make it, but how the work of art can lead the people to Him through the symbols produced. As quoted from Sumardjo (2000: 127) who explains that good art is able to provide experiences, both emotional and cognitive experiences, which "do not come from this world". The kingdom of art comes from outside this world. The starting point may be the experience of this world, but the result is not the experience of this world. That is the true greatness and excellence of art.

Mustika (2009: 9) explains that the main function of gamelan is to arouse one's beautiful feelings and can give satisfaction to the soul. Various investigations by music experts state that gamelan can function as therapy or treatments for mentally ill people. Likewise, in terms of aesthetic sense, harmonious gamelan songs can give beauty to players and admirers. Based on this, it can be understood that gamelan art is a combination of a general conception of beauty with a religious conception of beauty (aesthetics) based on the teachings of Hinduism. In general, beauty lies in a relationship between an object and the mind of someone who observes the object. So, an object has certain characteristics and that characteristic through perception appears in a person's consciousness, causing a sense of liking or enjoying the object (Gie, 2004: $50)$. The beauty referred to here is only limited to "enjoyment" of the senses of the observer (subject) so that it gives rise to a subjective view of the existence of a work of art. In contrast to art that contains Hindu aesthetic values, in this case it is associated with gamelan art which is not only "existed" with the intention of pampering the human senses and nature of mind, but also being dedicated to the Invisible Audience (God). Gamelan art is also made with all sincerity and as a medium to get closer to Ida Sang Hyang Widhi Wasa.

In particular, the concept of Hindu aesthetics according to Dibia (2003: 96) is a perspective on the sense of beauty (lango) which is bound by Hindu religious values based on the teachings of the Vedic scriptures. There are several concepts that would be an important foundation of Hindu aesthetics. The concepts in question include the concepts of holiness (Shiwam), truth (Satyam), and balance (Sundaram). Holiness (Shiwam) essentially concerns the values of Godhead which also includes yajña and taksu. Truth (Satyam) includes the value of honesty and sincerity. In accordance with the teachings of the Hindu religion, offerings and yajña made by the Balinese Hindu community should be carried out with full honesty, sincerity, and earnest intentions. Balance (Sundaram) which includes similarities and differences can be reflected in several dimensions. The existence of art which in this case is gamelan art, of course also contains three important foundations of the Hindu aesthetic. As described by Pendit, as follows: 


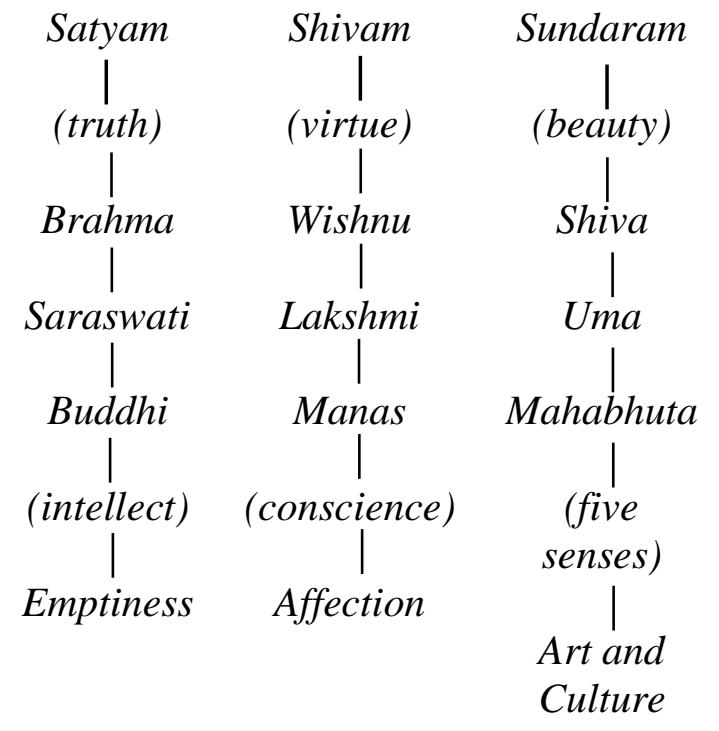

Only truth (emptiness) without virtue (compassion) and beauty (art and culture created by beauty) are inanimate objects; only virtue (love) without beauty (art and culture created by beauty) and truth (emptiness) is hysterical; only beauty (art and culture created by beauty) without truth (truth) and virtue (compassion) is a useless ceremony (Pendit, 1993: 119-120).

Truth (sathyam) basically concerns the values of Hindu religious teachings (tattva) which are sourced from the Vedic scriptures as the source of truth for the people, which are contained in gamelan art. The sound of the notes owned by the gamelan is believed to have a connection with the god who rules all directions. This concept is contained in the pangider bhuwana concept which is mentioned in one of the Balinese gamelan lontars, namely Lontar Prakempa. The sound of the tones of gong kebyar is used as a medium to connect with God in a ritual activity through gamelan playing in a Hindu ritual. In addition, one of the teachings contained in the Vedas is about the concept of "Vasudaiva Kutumbhakam", which is often interpreted as all beings are brothers. Gamelan art shows that here humans must work hand in hand like a family to be able to produce works of art, especially gamelan that can be enjoyed by everyone.

Chastity (Shivam) basically concerns the sincerity of the people in making offerings, because without sincerity, even a clean thing will not have the value of holiness. This includes the yajna and taksu contained in gamelan art. Yajna is a sincere sacrifice. The sincerity and sacred sacrifice referred to here is how gamelan artists sacrifice all their selfishness by playing gamelan in harmony to get closer to Ida Sang Hyang Widhi Wasa. By sacrificing all the selfishness of man, then man will achieve happiness and freedom itself, and with people doing sincere devotional service, then this is called the highest yajna. As contained in the following scriptures: Jyotiśca me, svaśca me, Yajňena kalpantam.

(Yajurveda XVIII. 1)

Translation :

May we attain enlightenment and happiness by means of sacrifice (yajňa) (Titib, 1996: 239).

While taksu is an allure that appears in the artist/artist or in his art, after getting the holy light of God (Dibya, 2003: 98). This gamelan art of course has its own taksu value, which makes gamelan art lovers come and enjoy every strain of gamelan. Without taksu, there will be no allure that attracts people to come and feel at home listening to the sound of the gamelan for a long time.

Sundaram itself is a value of beauty based on Hindu religious values contained in a work of art which in this case is contained by gamelan art. Beauty is, of course, an experience that is felt or interacted with the five senses. For this reason, gamelan art is created proportionally and takes into account the harmonization of tones so as to produce a dynamic in the embodiment of the results.

The combination of satyam (truth), shivam (holiness), and sundaram (beauty) is what makes arts related to Hindu religious rituals, especially those related to the existence of gamelan art, have aesthetic value, and their existence cannot be measured by material because it involves the taste value contained in it is enjoyed by 
both the gamelan artist and gamelan art connoisseurs.

\subsection{Ethics}

In terms of ethical values, gamelan art teaches one to learn to respect one another and learn the meaning of equality where everyone has the same position according to their respective duties and functions. Through gamelan, humans learn to harmonize what is said and what is done.

Ethics comes from the Greek ethikos, ethos (custom, habit, practice). As Aristotle used the term includes the ideas of "character" and disposition. The word moralist was introduced into the vocabulary of philosophy by Cicero. For him this word is equivalent to the word ethikos adopted by Aristotle. Both terms imply a relationship with practical activity. In many uses, this term is a synonym for the term "ethics" (Bagus, 2002: 217).

The word "moral" itself comes from English, namely moral; while from Latin it comes from the word moralis-mos, moris (customs, customs, habits, ways, behavior, behavior) mores (customs, behavior, character, character, morals, way of life). Some of the meanings of the word "moral" are as follows: (1) concerning human activities that are seen as good/bad, right/wrong, right/inappropriate, (2) in accordance with accepted rules regarding what is considered right. , virtuous, just, and proper, (3) has a) the ability to be directed by (influenced by) the realization of right and wrong, and b) the ability to direct (influence) others according to the rules of behavior that are judged right or wrong , (4) concerns the way a person behaves in relationships with other people (Bagus, 2002: 672).

The word "ethics" in a general sense is a form of human view regarding rightwrong, good-bad, right-incorrect, and other forms of comparison concerning the behavior of human life in their interactions in society, as well as concerning how humans as part of a social group behaves in social life. The word "ethics" here is also associated with the customs and habits of the community that have been carried out for generations. "Ethics" is not about the human condition, but how he should act.

The term "ethics" referred to in this paper is associated with the term "ethics" in Hinduism. Ethics in Hinduism is called susila which comes from the Sanskrit word, namely the word su which means good, and sila which means attitude or behavior. Ethics is one part of the Three Basic Frameworks of Hinduism, namely tattva or Hindu religious philosophy, ethics or Hindu religious ethics, and Hindu religious ceremonies or practices. Morals contain good interactions and mutual respect between one another, not only limited to humans and humans in social bonds, but also between humans and the surrounding environment, namely with other living things, namely animals and plants which also greatly affect human life.

Hindu ethics directs its people to meet the needs of humans themselves and control their desires wisely, in order to create balance in human life. ca iti dharma. As stated in the following quote:

Hindu ethics itself does not borrow the dogmatic terms of good and evil or heaven and hell. Hindu ethics exists because of the need to harmonize an individual's desires, emotions and ambitions to lead him to a harmonious life on earth, with the absolute goal of Hinduism being to realize our own existence. essence of human existence and freedom (Pandit, 2003: 135).

This Hindu morality or ethics does not oblige humans or members of society to always prioritize relationships in religious activities and ignore activities related to worldly activities and the fulfillment of human needs and desires. Hindu ethics or morality emphasizes how community members can harmonize all their actions and behavior as individual beings and social beings, and balance their needs and desires with activities related to intellectual 
and spiritual. As stated in the following quote :

Hindu ethics does not suggest suppressing desires and emotions, but satisfying those desires and emotions in controlled actions so that energy is not wasted on worldly pursuits. Sufficient energy must remain for intellectual and spiritual evolution. Some of the virtues that enhance the evolution of an individual are righteousness, nonviolence, love, justice, compassion, courage, wisdom, tolerance, pleasure, forgiveness, purity of thought, words and deeds, and selfcontrol (Pandit, 2003: 136- 137).

The Hindu ethical values contained in gamelan art as stated in the quote above is how the community, especially gamelan players, can balance and create good interactions between one player and other players to create harmonization in gamelan games. In addition, through this gamelan art, one player with another player is expected to respect each other, learn the meaning of equality where everyone has the same position according to their respective duties and functions. In gamelan art, no one player has a higher position than the other players. All have the same position and both have the duty and responsibility to present beautiful art for gamelan lovers. The educational value contained here is how gamelan players emphasize how they can harmonize all their actions and behavior as individual beings and social beings at the same time.

The value of ethical education contained in the art of gamelan also appears when studying the art of gamelan. Basically, to learn this gamelan art, it takes a good code of conduct to be able to master this knowledge. Without good ethics or behavior, knowledge about gamelan art is also impossible to master properly. The value of ethical education contained in this gamelan art is the application of the teachings of Tri Kaya Parisudha. Tri Kaya
Parisudha are three types of behavior that all human beings must purify. Tri Kaya Parisudha consists of Manacika Parisudha which means good and right thinking, Wacika Parisudha means saying good and polite, and Kayika Parisudha which means doing good and right. The teachings of Manacika Parisudha contained in learning the art of gamelan are how a gamelan player must always maintain the purity of his mind so that knowledge and skills of gamelan art can be obtained and practiced properly. In addition, gamelan art can also reduce the ripples of thought waves for both gamelan players and those who listen to the gamelan. Donder (2006:147) states that every object is a ripple, so every object, including living things (of course humans too) is a ripple, as quoted below :

The sound of gamelan that always accompanies Hindu rituals has a psychological effect on Hindus who attend the ritual, which can reduce the frequency of brain waves (thoughts) that are tense because they are tired, tired, and so on. The process of decreasing the frequency occurs because the frequency of gamelan sound waves can superpose the frequency of the waves emitted by the human brain. The joys and sorrows that hit mankind are in the mind, if the human mind is tense or frantic, the frequency of the thought waves tends to be at the betta frequency level $(\beta)$ which is $14-30 \mathrm{~Hz}$. In such a level, a person tends to get angry easily, for that pemedek, 'ceremonial participants' can lower the frequency level of his mind by diverting his mind to the sound of the gamelan. The frequency of the gamelan sound wave and the frequency of the thought wave will be superposed on each other. Over time the frequency of these thought waves will decrease to the alpha frequency $(\alpha)$ or other frequencies depending on the situation and 
condition of the person. (Donder 2005:160).

Based on the quote above, it can be understood that the art of gamelan can reduce the thought waves of both gamelan players and those who listen to the gamelan to a calmer thought wave. With a calm wave of thought, it will certainly make a person much wiser in dealing with all kinds of life situations. In addition, Donder (2005:154) also mentions that through the practice of clear thinking, you will be able to distinguish the types of gamelan sounds, the ability to distinguish these sounds will foster wiweka abilities which in the end can purify actions. The process of social ethics education obtained from the results of training or hearing the sound of the gamelan will occur naturally and is evolutionary. This quote leads to the understanding that gamelan art also contains the value of ethical education, especially the teachings of Wacika Parisudha and Kayika Parisudha, namely words and actions that are purified. From a clear mind that results from the process of decreasing thought waves through the gamelan, it also affects good words and actions as a result of good thoughts because basically the mind is the Indriya King which affects the work of the other senses and greatly affects human life. As stated in the quote from the sloka Sarasamuccaya 79 which reads :

Manasā nicayam krtva tato vaca vidhiyate, kriyate

Karmanā paṣcāt pradhānam vai manastatah

Translation :

So in conclusion, it is the mind which is the decisive element; if the determination of the feelings of the heart has taken place, then people begin to say, or do actions; Therefore, the mind is the main source (Kajeng, 1999: 66).

In addition, the ethical education contained in gamelan art is related to the attitude in playing the gamelan. After analyzing the teachings of Yoga, it turns out that the mechanism in playing gamelan has similarities to the mechanism in Yoga activity. The mechanism of Yoga teaching is applied in gamelan playing activities related to sitting posture (asana), breathing regulation (pranayama), and concentration (dharana). Through the art of gamelan, gamelan players are trained to sit well with their backs straight. In the teachings of Yoga, this attitude is intended to form a good posture. In addition, the habit of sitting with your back straight also gives the impression of being polite when sitting with other people. Gamelan art also teaches its players to practice breathing (pranayama). Pranayama comes from the word "prana" which means breath, energy and "chicken" which means length or length. Pranayama is a breathing practice in Yoga. By doing breathing exercises or pranayama regularly a person cleanses himself from the inside so that his mind will become calm (Somvir, 2007: 15). Through the regulation of the breath or pranayama, it can make the mind calm and will appear in one's words and actions. In addition, through the art of gamelan one is trained to always concentrate or in the teachings of Yoga it is called dharana. Good concentration will lead a person to be more focused and wise in carrying out his life. The mechanism has subtly explained that the education of ethical values related to attitudes in playing gamelan can be carried out or used as a spiritual medium in Hindu religious rituals.

\section{CONCLUSIONS}

Art can affect a person's character. One of the arts that can influence the soul is gamelan art or musical art. Almost every village in Bali has gamelan and has been played by all generations from children to adults. Gamelan is not only an art of introduction to dance or entertainment, but also has a sacredness because it has a philosophy of divinity in every sound produced by gamelan instruments. This sacredness is evidenced by the existence of a gamelan purification ritual during 
Tumpek Krulut or Saturday kliwon wuku Krulut.

The implementation of gamelan art directly or indirectly has educational values contained in it. Through gamelan art, humans will learn aesthetic and ethical values. From the aesthetic value, gamelan art contains the values of truth (Satyam), holiness (Shivam), and beauty (Sundaram) which are concepts of Hindu aesthetics itself. In terms of ethical values, gamelan art teaches one to learn to respect one another and learn the meaning of equality where everyone has the same position according to their respective duties and functions. Through gamelan, humans learn to harmonize what is said and what is done.

\section{REFERENCES}

Asnawa, I Ketut Gede. 2007. Kebhinekaan Dan Kompleksitas Gamelan Bali. Volume 6 No.1 September 2007: 26-51. Bheri Jurnal Ilmiah Musik Nusantara. Denpasar : ISI Denpasar.

Bagus, Lorens. 2002. Kamus Filsafat. Jakarta: Gramedia.

Bandem, I Made. 2013. Gamelan Bali Di Atas Panggung Sejarah. Denpasar : BP Stikom.

Dibia, I Wayan. 2003. Nilai-Nilai Estetika Hindu Dalam Kesenian Bali. Dalam Triguna, Ida Bagus Gde Yudha (ed). Estetika Hindu dan Pembangunan Bali. Denpasar : Program Magister Ilmu Agama dan Kebudayaan Universitas Hindu Indonesia bekerja sama dengan Penerbit Widya Dharma.

Donder, I Ketut. 2005. Esensi Bunyi Gamelan Dalam Prosesi Ritual Hindu Perspektif FilosofisTeologis, Psikologis, Sosiologis, Dan Sains. Surabaya : Paramita.

Donder, I Ketut. 2006. Brahmavidya : Teologi Kasih Semesta Kritik Terhadap Epistemologi Teologi, Klaim Kebenaran, Program Misi,
Komparasi Teologi, Dan Konversi. Surabaya : paramita.

Gie, The Liang. 2004. Filsafat Keindahan. Yogyakarta: Pusat Belajar Ilmu Berguna (PBIB).

Kadjeng, I Nyoman, DKK. 1997. Sarasamuccaya. Surabaya: Paramita.

Mustika, Pande Gede, dan Mawan, I Gede. 2009. Gamelan Gong Gede Di Pura Ponjok Batu Singaraja: Kajian Nilai-Nilai Ritual. Denpasar : ISI Denpasar.

Pandit, Bansi. 2003. Pemikiran Hindu. Surabaya: Paramita.

Somvir. 2007. Mari Beryoga. Denpasar: Bali India Foundation.

Suamba, IB Putu. 2003. "Siwa Nataraja: Simbol, Filsafat, dan Signifikansinya dalam Kesenian Bali", dalam Estetika Hindu dan Pembangunan Bali. Denpasar: Widya Dharma.

Suweca, I Wayan. 2007. Karawitan Bali Dalam Perspektif Rasa. Volume 20 No. 1 Januari 2007: 76-93. Mudra Jurnal Seni Budaya. Denpasar : ISI Denpasar.

Tim Penyusun. 1995. Kamus Besar Bahasa Indonesia Edisi Ke-2. Jakarta: Balai Pustaka.

Tim Redaksi. 2008. Kamus Besar Bahasa Indonesia Pusat Bahasa. Jakarta : Gramedia.

Yudabakti, I Made, dan I Wayan Watra.2007. Filsafat Seni Sakral Dalam Kebudayaan Bali.Surabaya: Paramita. 